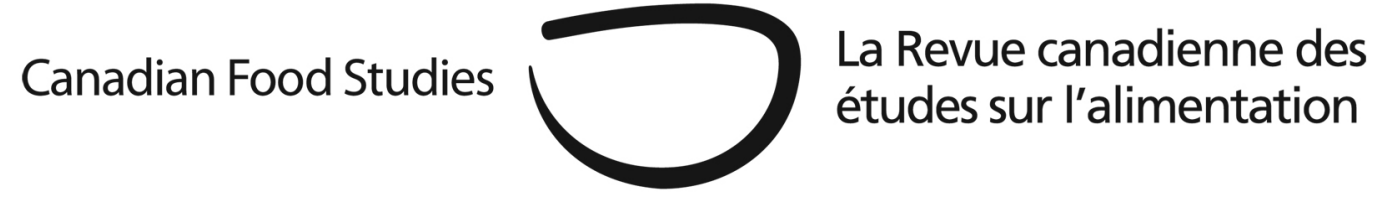

Section III

Global Food Trade

Special Issue: Mapping the Global Food Landscape

\title{
Food fight: What the debate about food security means at the WTO
}

\author{
Gawain Kripke \\ Policy Director, Oxfam America
}

\begin{abstract}
Although still experiencing significant levels of hunger and malnutrition, India has recently taken historic measures to improve food security, namely through the expansion of domestic food assistance programs. Under the Obama Administration, the U.S. has prioritized improving global food security and promoting agriculture development within the foreign policy agenda. President Obama has helped to lead the international community in reviving funding and attention to these issues. Yet, the U.S. has opposed the Indian food security program in negotiations at the World Trade Organization (WTO) by rejecting India's proposals to shield the program from possible WTO enforcement. The disagreement came to a head in the WTO Ministerial Conference in Bali, Indonesia in December 2013 and more recently at a senior-level WTO meeting in July 2014 where negotiations collapsed. The conflict is emblematic of disjointed policy debates and development theories around food security, agriculture, and trade.
\end{abstract}

The story so far...

In July of 2013, India's cabinet finalized historic legislation to dramatically expand subsidized food distribution to the country's poor people. Although criticized by the political opposition, the measure expanded food entitlements in the country: 67 percent of the population will have a legal right to obtain subsidized food grains through the country’s public food distribution system. 
The legislation is a capstone of more than a decade of campaigning and advocacy by civil society and other actors to advance the cause of a "right to food" in India (see Claeys, this issue). The campaign was an outgrowth of a 2001 public-interest legal petition to the Supreme Court of India that sought to extend the constitutional "right to life" to include a "right to food" and made specific demands of the government (Birchfield \& Corsi, 2010; Hassan, 2011; Right to Food Campaign, n.d.).

Campaigning to win national elections in 2009, the Indian Congress Party promised to enshrine the right to food in new national legislation. After the Congress Party was voted in, delivery of the campaign promise was delayed for years, in part due to political opposition. A high profile public debate emerged in India about food security, with Nobel Prize winning economist Amartya Sen stating that political opponents would be directly responsible for the death of children if the right-to-food policy was not put into place (TNN, 2013). However, critics of the plan argued it was an inefficient use of the national budget, that it would feed corruption, or that the program was a form of "vote buying." Finally, after building political and public pressure, the government finalized the legislation in July 2013, passed it through the parliament, and it went into force the following September. The Indian Congress Party-led government was subsequently rejected in national elections held in Spring 2014, however, the current government led by Prime Minister Modi of the Bharatiya Janata Party has upheld the legislation.

India, of course, has strong cause to take action on the issue of food security and malnutrition. The country is home to approximately one-quarter of the world's underfed people. India rates an "alarming" score on the Global Hunger Index, with close to 20 percent of the population undernourished and approximately 40 percent of children under 5 years old underweight (IFPRI, 2013).

Other countries have taken note of India's new food security program and some have indicated interest in using it as a model to address hunger (Joshua, 2013). Indeed, the United Nations' chief official in support of the human right to adequate food pointed to India's law saying, "It can inspire many countries to do the same thing" (PTI, 2013; see also Joshua, 2013).

However, immediately after the Indian food security law was enacted, India came under scrutiny from the WTO. The organization's Director General suggested, “India would soon be breaching their...commitments in the WTO” (Mehdudia, 2013). The trade policy problem India and other countries face is that their national food procurement processes-which set prices in advance of planting and purchase-can violate limits on agriculture subsidies that were agreed as part of WTO commitments. The crux of the issue is that if the government-set "administered price” deviates from the market price, then according to WTO rules there is an implicit subsidy to farmers, which is subject to WTO oversight and discipline.

India has repeatedly argued that its program does not violate the WTO limits on agricultural subsidies (ICTSD, 2014). However, recognizing that the new food security law might put India in violation of agriculture subsidy rules, the Indian government worked with an alliance of food importing and low-income countries (the Group of Thirty-Three [G33]) to 
develop proposals that would help shield similar food security programs from WTO enforcement and possible sanctions (Palmer, 2013). India and the G33 submitted several versions of proposals to adjust existing WTO rules and create more flexibility in the name of national food security, while being mindful to keep the basic structure of rules that restrict subsidies under existing WTO provisions intact (Burnett \& Murphy, 2014; De Schutter, 2011).

From the start, the U.S. set itself in opposition to India and the G33 proposal to create flexibility under WTO rules for food security programs. Highlighting U.S. disapproval, President Obama's trade envoy stated, "Frankly, the very essence of this proposal is confusing and concerning” (Palmer, 2013).

Ironically, the U.S. was making a strong diplomatic show of concern against a rather small problem in trade terms. While India is at risk of violating WTO trade rules on subsidies, the truth is that India's food procurement program was not very disruptive of trade. Recall that the reason to have WTO rules was to reduce and discipline international trade distortions. Yet, the prices Indian government paid for food commodities from local farmers to support the food security program were often lower than market prices. The primary reason for India and other countries to set such administered prices in advance is to give farmers some assurance when they plant, making this something tantamount to a forward or futures contract, which are not in widespread use in many developing countries. More importantly, the administered prices, even if they were above market prices, do not represent significant subsidies paid to farmers or distortionary premiums over market prices (Diaz-Bonilla, 2013). ${ }^{1}$

Providing support for Indian farmers is not the problem, rather the way in which subsidies are calculated on government food procurement are, being in large part an artifact of WTO rules. This is, in part, because the current calculation of reference price to which the "administered price" is compared, has been set, somewhat arbitrarily, to the period covering 1986-88. No inflation adjustment has been made, so current prices paid to procure food crops are compared to nominal prices from nearly 30 years ago. Without adjustment for inflation, current nominal prices seem very high by comparison. This, under WTO rules, leads to a calculation that shows large price premiums are being paid to farmers, implying large subsidies. However, if procurement prices are compared to 1986-88 prices (or actual market prices) and adjusted for inflation, then they are not nearly as high and it follows that the implied subsidies are consequently smaller (Matthews, 2014).

Thus, India is technically vulnerable to a WTO trade dispute for breaching permissible agriculture subsidy limits, even though in reality its actual agricultural subsidies are much smaller than what official calculations under WTO rules show. A deeper irony was that the U.S. was objecting to India's WTO proposal at the same time that the Obama Administration has made global food security and agriculture development a priority in the foreign affairs agenda. In June 2013, President Obama stated, "when I took office, we took a look at new ways that we could provide assistance and partner with countries, and we decided to make food security a

\footnotetext{
${ }^{1}$ Although countries are not explicitly named, this pattern is true in the example studies in Montemayor (2014, p. 11).
} 
priority" (Obama, 2013). In his first inaugural address, Obama notably said, "To the people of poor nations, we pledge to work alongside you to make your farms flourish and let clean waters flow; to nourish starved bodies and feed hungry minds” (Obama, 2009).

To support this vision, the Obama Administration launched the "Feed the Future" initiative, largely led by the U.S. Agency for International Development (USAID) with a goal to sustainably reduce global hunger and poverty through improved agricultural productivity (Feed the Future, 2014). The initiative has been funded at approximately US $\$ 1.1$ billion annually, reflecting a substantially increased rate of spending over previous Administrations. Feed the Future is not active in India. However, the initiative has a mandate: "to improve the effectiveness of our contributions to global food security, the United States must improve coordination within our own government.... To coordinate and align U.S. activities in Washington and in the field" (Feed the Future, 2010, p. 6).

As the high-level WTO Ministerial conference in Bali approached in 2013, the debate in Geneva devolved into a negotiation around the idea of a "peace clause." This idea was effectively a legal armistice that would protect India and other countries from the threat of legal challenge at the WTO while a "permanent solution" was negotiated. The U.S. was willing to offer a peace clause, but only under certain conditions, such as more transparency and reporting on the part of countries enjoying the protection. Yet talks on a peace clause nearly failed, with the Bali negotiations going into an extra day to achieve an agreement resolving the India-U.S. divide. More recently, in July 2014, at a meeting of senior representatives of WTO members, India withheld support for a finalized agreement on trade facilitation until it had assurances its food security programs would be protected from a WTO challenge. India's strategy was effectively a veto, since the WTO operates on a consensus basis rather than voting, requiring all members to agree to new rules for them to be passed. Trade facilitation was not directly related to the issue about food security and agriculture subsidies, but India used its political leverage to insist on a resolution to its concerns and an extension of the "peace clause." India's actions have been heavily criticized and the head of the WTO described the situation as "the most serious crisis the WTO has ever faced” (Agence France-Presse, 2014).

\section{Explaining the U.S.-India food fight}

The Indian food security program can be described as having three important components: a) procurement of food commodities; b) stockholding of food; and, c) distribution of subsidized food to targeted populations. Note that the program is extremely complex as it is largely administered by states, with substantial variation in implementation policies and practices. Many of the components of the federal program have been in place for decades, however, it was only when India made it a national program that it inspired controversy at the WTO.

A closer look reveals that the primary issue being fought over at the WTO is the first component, the procurement of food by the government. Ironically, it is the second component, 
the public stockholding of food and the management of the reserves, that probably has more significant trade impacts. India has made large public releases into the Indian market of rice and wheat from stocks, which can have the effect of depressing prices and displeasing food exporters (Oryza.com, 2014; Sen, 2014; TNN, 2014). For example, in 2012, India released two million tons of wheat from central stockpiles at subsidized prices to reduce overflowing stocks (ICTSD, 2012; PTI, 2012). This pattern is becoming more frequent as India has accumulated very large food reserves in recent years and continues to release stocks periodically. Critics point out that India has also now become a significant exporter of wheat and is the world's top exporter of rice, so management of food security reserves has significant trade implications. Nonetheless, WTO rules offer very little constraint on stockholding per se (Josling, 2014).

The consumer subsidy for reduced-rate distribution of foods is the most expensive element of the Indian food security program, and thus has the greatest so-called subsidy generating aspect (i.e., subsidized food prices). This subsidy makes up the largest single cost of the approximately US\$13 billion Public Distribution System (Hoda \& Gulati, 2013). Under the new Food Security Law, the overall costs are projected to rise to more than US\$20 billion annually in order to reach two-thirds of India's 1.2 billion people. By comparison, the U.S. food stamps program costs nearly six times more at about US\$80 billion and only reaches approximately 45 million Americans in the form of food vouchers (CBPP, 2014). At the WTO, there is no challenge to these kinds of consumer-oriented subsidies for food assistance.

Whatever the merits of the debate at the WTO, it has the optics of the U.S. opposing and obstructing India's pursuit of domestic food security. This is, on its face, quite a contradiction with President Obama's statements around cooperating internationally for improved agriculture and food security. It also highlights inconsistency between different branches of government, with USAID pursuing one course, but with the U.S. Trade Representative (USTR) negotiating another.

More generally, the dispute is a clear example of the contradictions between food security and international trade rules, something that many civil society groups have highlighted for years. $^{2}$ In general, the criticism of trade rules (enforced by international trade agreements such as those under the WTO) is that they constrain governments' policy options and narrow the available modalities for governments to undertake food security programs. Advocates of free trade have long dismissed this argument. However, with India having taken an historic step towards food security and fulfilling the human right to food, it now clearly faces opposition and potential challenges at the WTO.

In terms of specific consequences from the food fight, the jeopardy that India and other developing countries face is disciplinary enforcement (i.e. economic sanctions and being forced to dismantle the program) for violating WTO agreements limiting agriculture subsidies. This is a highly technical issue that has important long-term implications because such programs are seen to diverge from the underlying purpose of the agreements, which is to liberalize agricultural

\footnotetext{
${ }^{2}$ Note: the author works for a non-profit organization, Oxfam America, and is generally writing from a civil society perspective.
} 
trade and reduce distortion of markets by governments. Yet India's subsidies, as defined by the WTO, do not necessarily reflect actual distortionary market interventions. And the impact on real international food trade is even more removed.

\section{Disconnects in U.S. policy}

As noted above, there is a disconnect in U.S. policy in support of food security, on the one hand, and in opposition to India's expanding food security program at the WTO. There is also a strange hypocrisy on the part of the U.S. (and also the European Union [EU]) in criticizing India for pursuing policies that have historically been (and indeed still are) part of U.S. and European agricultural policy.

The U.S., for example, continues to provide government-set minimum price guarantees for many commodities, most recently reauthorized as part of the 2014 Farm Bill enacted by Congress and signed into law by President Obama. As recently as the 1980s, the US government held large stocks of surplus commodities, which it sought to dispose of through exports or foreign aid. Of course, the U.S. government also has an extensive food assistance program, through both commodity distribution and cash allocations (vouchers). Under WTO rules, the U.S. is permitted much larger farm subsidies than is India, even though agriculture in the U.S. is a much smaller fraction of economic activity and employment. The unfairness is glaring.

Another disconnect is to consider whether India's Food Security program, in particular the Public Distribution System, actually improves food security. This is less clear and continues to be debated. First, it is widely agreed to be highly inefficient with massive food wastage through poor storage as well as misdirection through corruption, political capture, and low technical capacity. According to an internal government report, "leakage" of grain could be as high as 58 percent overall and even higher in some states (World Bank, 2011, p. xiii). The resource loss is monstrous and tragic.

At the same time, even when it does work, it is clear the Public Distribution System has not done enough to eliminate hunger, given persistent high levels. It may be the case that the program is badly designed to address the most important parts of food insecurity, such as child stunting. Subsidized cereals provide an important consumer income transfer by effectively making food cheaper. However, cereals themselves are often not important in reducing malnutrition, either because they offer the wrong nutritional components, or because poor consumers already get enough cereals. More targeted, nutritionally diverse, and more nutritionoriented interventions might have much higher impacts than the current system (the Public Distribution System also offers some pulses and other foods).

India’s Public Distribution System clearly has problems, yet there is political will to do more. This political will was demonstrated with the passage of the Food Security legislation in 2013, and, apparently, by the continued support for the program by the Modi government. So, the question is, can the pressure from the WTO negotiations be converted into pressure to 
improve the program on its own terms, in favor of food security and program efficiency? And can the U.S., with its newfound commitment to global agriculture development and food security, find a way to channel its influence in this direction rather than in an obstructionist, adversarial way?

One important conceptual disconnect is between paradigms for food security (see Wise, this issue). One is the neoliberal paradigm, which posits increased economic liberalization (especially trade liberalization) as a mechanism for improved food security. This paradigm envisions improved food security, first through increased trade openness, which permits the movement of food from food surplus regions to food deficit regions. Food is thereby provided more consistently with prices mediated by geographic risk pooling. Second, it posits that food security can be improved through higher economic growth that will result from increased economic liberalization, which in turn will raise incomes and food access.

An alternative paradigm for food security relies on more affirmative action by governments to uphold a human right to food (see Narula, this issue). A range of policy measures support this paradigm, including: public subsidy for food access, targeted support for lowresource farmers to increase production and improve livelihoods, and public stockholding to mediate prices. A strong state role and managed trade flows help support this approach.

These paradigms are not necessarily in contradiction. However, they remain contentious in certain fora, like the WTO.

Questions for further research and analysis:

1. Can the WTO facilitate substantive improvements or supports to the Indian food security program? Could the jeopardy posed by WTO rules be converted into an opportunity to support the goal of improved nutrition and food security for hundreds of millions of poor Indians?

2. Can the Obama Administration's food security goals and its trade negotiation position be reconciled and rationalized? What steps could bring them into alignment?

3. While India is, by itself, a major factor in global food security because of its sheer number of food insecure citizens, there is a question about how important or relevant India's food security program is or could be to other countries. How replicable is India's program? Are there conditions in which it would be a good or bad model? 


\section{References}

Agence France-Presse. (2014, November 8). Customs impasse is WTO's 'most serious crisis'. GlobalPost. Retrieved from http://www.globalpost.com/dispatch/news/afp/141108/customs-impasse-wtos-mostserious-crisis

Birchfield, L., \& Corsi, J. (2010). The right to life is the right to food: People's Union for Civil Liberties v. Union of India \& Others. Human Rights Brief, 17(3), 15-18.

Burnett, K., \& Murphy, S. (2014). What place for international trade in food sovereignty? Journal of Peasant Studies, 41(6), 1065-1084.

Center on Budget and Policy Priorities (CBPP). (2014, June 4). Policy basics: Introduction to SNAP. Washington: Center on Budget and Policy Priorities. Retrieved from http://www.cbpp.org/cms/index.cfm?fa=view\&id=2226

De Schutter, O. (2011, November). The World Trade Organization and the post-global food crisis agenda: Putting food security first in the international trade system (Briefing Note 4). New Work: United Nations. Retrieved from www.srfood.org/images/stories/pdf/otherdocuments/20111116_briefing_note_05_en.pdf

Diaz-Bonilla, E. (2013, December 5). Some ideas to break the stalemate on agricultural issues at Bali. Food Security Portal. Retrieved from http://www.foodsecurityportal.org/some-ideasbreak-stalemate-agricultural-issues-bali

Feed the Future. (2010, May 1). Feed the Future Guide. Washington: U.S. White House. Retrieved from http://feedthefuture.gov/sites/default/files/resource/files/FTF_Guide.pdf

Feed the Future. (2014). Progress Report. Washington: U.S. White House. Retrieved from http://www.feedthefuture.gov/progress

Hassan, S. (2011, April). Rights, activism and the poor in India: Supreme Court and the 'Right to Food case'. Paper for International Conference Social Protection for Social Justice. UK: Institute for Development Studies. Retrieved from https://www.ids.ac.uk/files/dmfile/hassan2011therighttofoodcaseinindiacspconferencedraft .pdf 
Hoda, A., \& Gulati, A. (2013, September 1). India's agricultural trade policy and sustainable development. International Centre for Trade and Sustainable Development. Retrieved from http://www.ictsd.org/downloads/2013/09/indias-agricultural-trade-policy-and-sustainabledevelopment-goals.pdf

International Centre for Trade and Sustainable Development (ICTSD). (2012, July 18). India wheat export decision sparks food security, trade concerns. Bridges, 16(28). Retrieved from http://www.ictsd.org/bridges-news/bridges/news/india-wheat-export-decision-sparksfood-security-trade-concerns

ICTSD. (2014, September 18). India reports farm subsidies beneath current WTO ceilings. Bridges, 18(30). Retrieved from http://www.ictsd.org/bridges-news/bridges/news/indiareports-farm-subsidies-beneath-current-wto-ceilings

International Food Policy Research Institute (IFPRI). (2013). Data underlying the calculation of the GHI scores, IFPRI. Retrieved from https://dataverse.harvard.edu/dataset.xhtml?persistentId=doi:10.7910/DVN/22795

Joshua, A. (2013, October 12). Indonesia keen on India’s Food Security law. The Hindu. Retrieved from http://www.thehindu.com/news/international/world/indonesia-keen-onindias-food-security-law/article5229331.ece

Josling, T. (2014, September 18). The WTO, food security and the problem of collective action (unpublished paper). Washington: World Bank. Retrieved from http://www.worldbank.org/content/dam/Worldbank/Event/DEC/DECAR-food-conferencesep-2014/DECAR-Food-Conference-Sep18-19-Paper_Josling-The WTO and Food security.pdf

Matthews, A. (2014, June 1). Food security and WTO domestic support disciplines post-Bali. International Centre for Trade and Sustainable Development. Retrieved from http://www.ictsd.org/sites/default/files/research/Food\%20Security\%20and\%20WTO\%20D omestic\%20Support\%20Disciplines\%20post-Bali.pdf

Mehdudia, S. (2013, October 7). WTO chief raises concerns over India food security law. The Hindu. Retrieved from http://www.thehindu.com/news/national/wto-chief-raises-concernsover-india-food-security-law/article5210505.ece

Montemayor, R. (2014, June 1). Public stockholding for food security purposes: Scenarios and options for a permanent solution. International Centre for Trade and Sustainable Development. Retrieved from http://www.ictsd.org/sites/default/files/research/Public 
Obama, B. (2009, January 21). President Barack Obama's inaugural address. Washington: U.S. White House. Retrieved from http://www.whitehouse.gov/blog/inaugural-address

Obama, B. (2013, June 28). Remarks by President Obama after food security expo. Washington: U.S. White House. Retrieved from http://www.whitehouse.gov/the-pressoffice/2013/06/28/remarks-president-obama-after-food-security-expo

Oryza.com. (2014, January 28). Pakistan raises concerns about India rice subsidies at WTO. Retrieved from http://www.oryza.com/news/rice-news/pakistan-raises-concerns-aboutindia-rice-subsidies-wto

Palmer, D. (2013, December 3). WTO begins talks to save pact, reputation. PoliticoPro. Retrieved from http://www.politico.com/story/2013/12/wto-conference-global-trade-pact$\underline{100576 . h t m l}$

PTI. (2012, December 16). India's wheat exports likely to touch $6 \mathrm{mn}$ tonnes: USDA. The Hindu. Retrieved from http://www.thehindu.com/business/Industry/indias-wheat-exports-likely-totouch-6-mn-tonnes-usda/article4206240.ece

PTI. (2013, July 4). India's food law can inspire many countries: UN official. The Economic Times. Retrieved from http://articles.economictimes.indiatimes.com/2013-0704/news/40372063_1_food-law-food-inflation-food-programme

Right to Food Campaign. n.d. The 'Right to Food' Case. Retrieved from www.righttofoodcampaign.in/legal-action/-right-to-food-case

Sen, A. (2014, January 27). Canada, Pakistan frown at India's food grain exports, farm subsidies. The Hindu Business Line. Retrieved from http://www.thehindubusinessline.com/economy/canada-pakistan-frown-at-indiasfoodgrain-exports-farm-subsidies/article5623852.ece

TNN. (2013, May 7). Amartya Sen links House disruptions to child deaths. The Times of India. Retrieved from timesofindia.indiatimes.com/india/Amartya-Sen-links-House-disruptionsto-child-deaths/articleshow/19924768.cms

TNN. (2014, February 3). India's wheat, rice exports raise hackles at WTO. Economic Times. Retrieved from http://articles.economictimes.indiatimes.com/2014-0203/news/46963233_1_tonne-floor-price-food-subsidies 
World Bank. (2011). Social protection for a changing India (Volume I). Washington: The World Bank. Retrieved from www-wds.worldbank.org/external/default/WDSContentServer/WDSP/IB/2011/04/20/ 000333037_20110420235516/Rendered/PDF/612750v10ESW0P1rt0 Volume0I01PUBLIC1.pdf 